\title{
Partnerships in action: establishing a model of collaborative support to student and mentor teachers through a university- school partnership
}

\section{Patti Silbert and Clare Verbeek}

\begin{abstract}
South African universities have a crucial role to play in helping reduce inequalities in schooling by preparing teachers for working across diverse school contexts. This article examines a pre-service teacher collaborative support programme generated through a twoyear action research process. The programme was designed to support student teachers and their school-based mentors during Teaching Practice through an existing university-school partnership. Using a qualitative analysis of journal entries and separate focus group discussions with student and mentor teachers we describe students' and mentors' responses to the collaborative support programme. The findings of the study suggest that a collaborative support strategy pitched at both the university and school is critical to support student teachers during their pre-service teaching, especially in socially and educationally challenging contexts. Joint responsibility for initial teacher development requires a reconceptualisation of the role of the mentor teacher, and a shift towards the distribution of mentoring functions from a few designated mentor teachers to include a wider range of teachers at the school.
\end{abstract}

\section{Introduction}

Internationally there is a growing body of literature that regards universityschool partnerships as central to initial teacher training. Pivotal to the notion of partnership is reciprocity and collaboration - and the development of mutually beneficial relationships (Nehring and O'Brien, 2012; Fink, Isabelle and De Groot, 2010) to strengthen capacity at both the university and the school. As Corrigan (2000) points out, collaboration extends beyond cooperation and coordination and implies that something new is enabled or produced that individuals or organisations could not produce alone. This has direct implications for the role of the university-school partnership in teacher training. 
Twenty years post apartheid, schooling in South Africa remains sharply unequal, to the extent that it has been referred to as a dualistic or bimodal system (Fleisch, 2008; Spaull, 2012; Van der Berg, Burger, Burger, De Vos, Du Rand and Gustafsson, 2011; Yamauchi 2011). The need for professionally qualified teachers must be seen in the light of the increasing demand for quality education, particularly in unequal and disadvantaged school contexts. As universities engage in the initial professional development of teachers, they have a critical role to play in helping reduce inequalities in schooling by preparing excellent teachers for working in all school contexts (Mutemeri and Chetty, 2011; Islam, 2011; Robinson, 2014, 2015; Pennefather, 2008, 2011). A crucial aspect of this preparation involves exposing student teachers to schools across diverse schooling communities during their compulsory Teaching Practice (TP) enabling them to develop and practise innovative pedagogies within those contexts. However, placing student teachers in challenging school contexts requires careful support both for student teachers and the schools themselves if this is to contribute effectively to the initial professional development of teachers.

Teaching Practice traditionally involves the placement of student teachers in the classrooms of mentor teachers who, as more experienced and knowledgeable professionals, provide important opportunities for professional development through collaboration in planning, teaching and assessment, thus contributing to the construction of personal and professional identities (Mukeredzi, 2013; Robinson 2015). Such support needs to be formal and planned and should link theory to practice through dialogical engagement (Mukeredzi, 2013). Much of the recent research in the Southern African context has pointed out the uneven support offered by such mentors to student teachers (Kiggundu and Nayimuli, 2009; Mukeredzi, 2013; Mukeredzi and Mandrona, 2013; Mushoriwa and Mavuso, 2014; Mukeredzi, Mthiyane and Bertram, 2015) and has called for the provision of support for the mentors themselves through ongoing training and development, stressing the need to build partnerships for this provision.

The purpose of this article is to describe a two-year action research project that focused on a collaborative programme of support offered to student teachers and their school-based mentors through an existing university-school partnership. The university-school partnership is presented as a vehicle through which distributed support was offered to student teachers as part of their intitial professional devlelopment. 
The term 'mentoring' implies support given by a more experienced teacher for the professional growth and learning of a student teacher. The notion of 'support' in this study includes emotional (Rajuan, Beijaard and Verloop, 2008) and organisational factors that contribute towards professional development of both student and mentor teachers. 'Distributed support' involves acceptance of joint, collaborative responsiblity for initial teacher development by a number of partners including the teachers. Providing this level of support reflects a commitment by both the university and the schools to the development of quality schooling in contexts which are historically challenged.

It is against this background that the study seeks to address the following questions:

1. What type of collaborative support strategies are possible through a university-school partnership?

2. What are the implications of such collaborative support for school-based mentoring?

Signalling Robinson's 2014 study in which she calls for a conceptual model of teacher education that supports teacher preparation for diversity, we argue that a generic approach to TP is inappropriate and that the model of support provided by universities needs to be adapted to the specific context in which TP takes place. Furthermore, it is not only the student teachers who require support: supportive mechanisms also need to be implemented for the mentor teachers who are called upon to support the students in what might be new and unfamiliar ways. Underpinning these two areas of support, we assert that university-school partnerships can provide the type of collaborative engagement through which support mechanisms can be offered both at the level of the university and the school.

\section{University-school partnerships in initial teacher training}

In this study, the notion of the university-school partnership to promote initial teacher training is embodied in the idea of the Professional Practice School (South African Departments of Basic Education and Higher Education and 
Training, 2011) which refers to schools as professional learning sites at which student teachers are placed for the practical components of their programmes. Professional Practice Schools should be located in a variety of social and education contexts and are intended to provide opportunities for student teachers to engage in learning in practice through preparing, teaching and reflecting on lessons (Robinson, 2014). The importance of close collaboration between universities and Professional Practice Schools schools in diverse contexts is underscored in this study.

The type of university-school partnership referred to through the Professional Practice School suggests a transformative relationship between universities and schools where both partners "retain their identities but are willing to learn from and with each other" (Teitel, 2008, p.78), assuming joint responsibility for teacher professional development. Introducing the notion of 'hybrid spaces', Zeichner (2010, p.89) refers to this co-constructed engagement as "a paradigm shift in the epistemology of teacher education programes" in which "academic and practioner knowledge and knowledge that exists in communities come together in new less hierarchical ways" in order to create new learning opportunities for student teachers (see also Mutemeri and Chetty, 2011). In this sense, the school becomes a site in which learning about the practice of teaching and the practices of schooling can occur both through practice and in practice (South African Departments of Basic and Higher Education and Training, 2011).

While all schools used for the purpose of professional onsite learning might be regarded as Professional Practice Schools, the term as used in this study refers to the particular set of schools involved in the USPI ${ }^{1}$ university-school partnership. These schools fall into the category of what Christie, Butler and Potterton (2007) would describe as 'mainstream' schools in South Africa. Such schools constitute the 'numeric norm' (Christie, Butler and Potterton, 2007, p.100) and are situated somewhere between the elite and the extremely poor, populated largely by black students and teachers, with limited physical resources. English is used as the language of teaching and learning, rather than the home language of the majority of teachers and their learners.

'Mainstream schools' are typical of urban and peri-urban township areas such as those that comprise the site of the USPI partner schools. It is this type of school context plagued by socio-economic problems of poverty, crime and 
unemployment, for which student teachers need to be appropriately prepared in order to make a positive difference.

The role of mentor teachers within the university-school partnership model is reported on in numerous studies (Hall, Draper, Smith and Bullough, 2008; Hobson, 2002; Teitel, 2008; Mutemeri and Chetty, 2011; Stanulis and Russell, 2000, amongst others). Hobson's (2002) study refers to mentoring undertaken not merely by teachers assigned as 'mentors' but by other teachers at the school. Students' perceptions of their school-based mentoring experience has been researched by a number of scholars (Rajuan, Beijaard and Verloop, 2008; Hobson 2002; Zanting, Verloop and Vermunt, 2001, and others). In South Africa, recent research on Teaching Practice has focused on rural schools (Pennefather, 2008; Mukeredzi, 2013; Mukeredzi and Mandrona, 2013; Mushoriwa and Mavuso, 2014), and on the types of knowledge which mentors help student teachers develop (Mukeredzi, et al. 2015).

The need to provide more effective training opportunities for mentors is highlighted by numerous scholars in the field, including Hudson, SpoonerLane and Murray (2013); Hobson (2002); Hall, et al. (2008), and Mukeredzi, et al. (2015). As Robinson (2014) asserts, developing robust mentoring practices is particularly important in a country such as South Africa, where mentors help students to prepare to teach in diverse contexts. This has direct implications for the ways in which universities "might best contribute to serving learners in difficult social contexts" (2014, p.115).

Mukeredzi, et al. (2015) call for committed dialogue between all stakeholders, including teacher educators, education departments and schools on preservice teacher support. According to these authors, "( $\mathrm{t}$ )his implies that institutions ought to take a lead in developing and/or maintaining strong partnerships between schools and universities, and in ensuring that appropriate strategies are put in place to enhance mentoring effectiveness" (p.9) .

Despite the plethora of scholarship, there has been no South African study to date that examines an initial teacher education action research programme as an integral component of an existing university-school partnership. Nor has there been any study that considers the possibilities for distributed support within that partnership. 


\section{The University-School Partnership Initiative (USPI)}

The USPI was launched in 2012 as one of the university's strategic initiatives, linking the university to a number of schools in a poor urban Western Cape township. The overarching aim of the USPI is the development of a strong, responsive university-school partnership as a medium for extending the university's engagement in schooling in order to contribute positively to longterm change in the classroom. Focusing on whole-school development, the USPI's programmes involve teacher professional development, leadership capacity building and school organisational development. Drawing on interdisciplinary university-wide resources and expertise, the USPI collaborates with partners both within and outside of the university including, significantly, the district level provincial education authorities. Additional programmes offered through the partnership involve library support; school health services; IT development; after-school homework clubs and sports programmes. The USPI's objective of forming partnerships with other education-related groups within the university and the broader community is based on the understanding that the improvement of the quality of educational provision requires collaboration and involvement of all those involved in education including most importantly, the schools themselves.

Moving away from the traditional view of Teaching Practice in which the school is expected mainly to provide a site for students to conduct their practice teaching (Mutemeri and Chetty, 2011), a collaborative model of teacher development positions the school (and its teachers) as an active partner, and an "essential contributor to the programme" (p.506). This shift in the relationship between the university and the school from limited community engagement to the establishment of deeply collaborative partnerships has been advocated as an approach for improving the practice of teacher training (Ramsey, 2000; Deppeler, 2006; Mutermeri and Chetty, 2011; Rutgers and Reddy, 2013; Islam, 2011; Pennefather, 2011, Mukeredzi, et al., 2015). Through strong, mutually beneficial collaboration, the USPI seeks to address inter alia, in-service teachers' professional development needs within the schools, while providing opportunities for student teachers to broaden their experience in the classroom across a range of school contexts.

Rather than being an aim in themselves, partnerships are regarded by the USPI as a means to improve the quality of the engagment between the parties. 
The strength of this objective lies in its potential to create the space for new types of collaborative support for student and mentor teachers.

\section{Background to the USPI support programme}

At the university involved in this study, initial teacher education programmes are offered for the Foundation, Intermediate, Senior and Further Education and Training phases ${ }^{2}$ of schooling through a one-year post graduate professional qualification (Post Graduate Certificate in Education or PGCE) which caps an initial undergraduate degree. The school-based component of this qualification requires that students complete two six-week periods of supervised TP in schools. At this university an attempt is made to ensure that this is undertaken in two differently provisioned schools, enabling students to experience diverse school contexts.

In both 2013 and 2014, Intermediate Phase student teachers were invited to apply for placement in the PPS programme. The large number of applicants in both years suggested a high level of interest amongst students, all of whom had undertaken their first TP in better resourced schools. Financial support for transport was provided as the schools are located 50-60 km from the university. The number of students accepted into the programme was limited by the funds available as well as by the availablility of mentor teachers in the schools: in 2013 a total of six students were involved (two in each of the three partner schools) and in 2014, this number grew to eleven (four in two schools, and three in the third).

The programme included support for students by a university-based supervisor as well as by education specialists from the the Language and Maths Development Project (LMDP). ${ }^{3}$ The LMDP is a university based project supporting effective instruction in Mathematics, English and isiXhosa. In the study, LMDP education specialists played an important role in complementing support given to student teachers. Lesson planning, reflection

2 The South African schooling system is divided into different phases: Foundation (Grades R-3); Intermediate (Grades 4-6); Senior (Grades 7-9) and Further Education and Training (Grades 10-12).

3 This is a pseudonym. 
and the sharing of ideas took place both in the schools (on at least one occasion during the TP) and on a weekly basis at the university.

\section{Methodology}

In this study, the action research methodology is characterised by cycles of action, evaluation and critical reflection by participants on practice (Meyer 2000; Kemmis and McTaggart, 2000; Koshy, Koshy and Waterman, 2010). Participants included mentor teachers, the university supervisor, the LMDP team and the student teachers. The three schools involved were partner primary schools with the USPI. In each school there were two mentor teachers who were selected by the principals and school management teams (SMT), and who were receptive to assuming the mentoring role. Three of the six mentor teachers were members of the SMT and all of the six mentors had been teaching at their school for at least five years. Only one mentor teacher had previous experience mentoring student teachers and none had received any prior formal training in mentoring or developing student teachers. Of the mentor teachers, five out of the six remained involved over the two-year period of the study, the sixth mentor having to withdraw in 2014 for health reasons.

Student involvement was entirely voluntary. A presentation on the three partner schools was offered to the PGCE students who were interested in these placements. Of the eighteen students, two were male, sixteen were female, two were isiXhosa-speaking and sixteen were English first-language speakers.

An interpretive, thematic approach was used for the analysis of data, allowing for the emergence of dominant themes and patterns across the texts. Two methods were used for collection of the student data: in-depth focus group discussions and students' reflective journals compiled during their TP. Similarly, in the case of the mentor teachers, data was collected from focus group dicussions and mentors' journals compiled during the six-week Mentoring Short Course. Written feedback was given by the LMDP which also served as a source of data.

Quality, validity, accuracy and credibility of research findings were enhanced by repetition of the action-reflection cycle, prolonged engagement with the 
issues, polyangulation of data and member checking (Mertler, 2012). Validation was sought by incorporating multiple sources of data from different role-players including interviews, reflective journals, written responses and focus group discussions (Stemler, 2001). Pseudonyms were used at all times.

The analysis that follows is logico-inductive, based on a qualitative action research design and was constructed from data collected over a two-year period. As such the action research process comprised two action-reflection cycles:

Action reflection cycle 1: 2013

- Interviews with mentor teachers conducted prior to the commencement of the 2013 TP block provided an opportunity for mentors to share expectations and perceptions regarding their anticipated roles as mentors.

- $\quad$ Six-week TP and school-based mentoring.

- $\quad$ Following the 2013 TP block, separate focus group discussions with the mentors and student teachers allowed both groups to reflect on their experiences. This helped inform future practice.

Action reflection cycle 2: 2014

- The Mentor Teacher Short Course which took place prior to the commencement of the 2014 TP block was conceptualised to address the mentors' needs, as expressed in their focus groups discussions in 2013.

- $\quad$ The six-week TP and school-based mentoring included the placement of two student teachers in each class as a strategy to encourage peer support.

- Following the $2014 \mathrm{TP}$, focus group discussions were held once again with the mentors and student teachers, to reflect on and evaluate their experiences. As in 2013, discussions with mentors and students took place separately. 


\section{Discussion}

Three main themes were identified from the data across both action reflection cycles. Two of the themes, distributed mentorship and distributed support pertain to the professional development of student teachers and support for the school-based mentors in helping the students achieve this. The third theme, imagining mentoring emerged from the first two and refers to the student teachers' views of mentoring, the mentors' perceptions - and to possible ways of re-conceptualising mentoring roles.

The discussion is structured according to these themes within the two action research cycles. We begin by describing the students' reflections from the first and second cycles and thereafter consider the reflections of the mentor teachers.

\section{Distributed mentorship across the schools}

Distributed mentorship involved two broad levels of support by teachers in general: firstly, this pertained to teachers taking responsibility for developing the students by giving them valuable feedback, and secondly, teachers making an effort to welcome students into the school environment. Both levels of support were demonstrated in varying degrees both by mentor teachers, and by teachers not formerly designated as mentors (hereafter referred to as 'nonmentor' teachers).

With regard to the role of the mentor teachers firstly, students generally felt nurtured and cared for, however there were few examples of mentors offering critical feedback on lessons taught by students. One student reflects positively in this regard:

She was an amazing mentor in terms of our general well-being and always looked out for us. She had our best interest at heart. She was extremely professional. I never felt confused about what she wanted from us. She was very approachable, and although she did not give a lot of critical feedback she was willing to listen to us when we had questions and was always willing to try answer our questions, which was really good mentorship. She also did do a formal critical analysis for us in the end in a written form, which was very helpful.

However, on the whole students felt that insufficient critical reflection by mentors took place after lessons were taught and that feedback seldom went 
beyond comments such as "that was good, you are doing fine". Similarly students received little input regarding lesson planning or guidance from their mentors before teaching their lessons. As one of the students suggests:

I didn't get advice on what to do. It was sort of "here you go, just do it on your own. Just follow the text book and open the teacher's guide". So there was no sort of guide on how to do the actual planning.

In a different school, a student indicates that although her mentor teacher was present when the student taught lessons, the mentor did not engage with her about the lessons taught:

I remember the first time I taught was like, “you don't even need to be here. They should just give you a certificate". . . and after that she never really gave me feedback on other lessons that I wuld do, but she would be there in the classroom doing other things like admin.

Accounts by student teachers of the role played by non-mentor teachers suggest that teachers not assigned as mentors were at times more engaged. Students were linked with non-mentor teachers either if the mentor was absent of if the mentor's learners were writing tests. At other times student teachers were spontaneously invited by non-mentors to teach their classes. Students reflected positively on the support given by non-mentors which frequently served to enhance feelings of belonging within the school community:

Ms Simdini, she became our mentor teacher indirectly, like she'd always be there in the mornings, (asking) "how's everything going? What are you doing today?" She's the Maths HOD. She'd give us advice, she'd give suggestions. . . She just fell into a mentoriship role for us.

A student (in a different school) also reflected positively on the feedback offered by a non-mentor teacher:

The other Grade 4 teacher was very nice. I had an art lesson and ... she gave us good feedback .... She gave me feedback as to how I could change it, and that's what I think mentor teachers should be like ... I think she would make a good mentor teacher.

Support by non-mentor teachers highlights Hobson's (2002) conception of the role of mentoring which he argues should extend beyond assistance given by designated mentor teachers to include other teachers whose advice and support may be sought. This underscores the importance of participation by all teachers in the mentoring process and, as shown in the data, signifies the 
value of different levels of interaction and support. Instances of hospitality and care for example, were often mentioned, as suggested below:

In the schools the staff were all very helpful and accommodating and went out of their way to make us feel comfortable.

Deepening the concept of the Professional Practice School, distributed mentoring implies that the whole school is concerned with the professional development and wellbeing of student teachers. At the level of the university, the notion of distributed support similarly extends and broadens the support functions across a wider group of professionals. What follows is a description of the collaborative support programme offered through the USPI, and student teachers' responses to this programme.

\section{Distributed support by the USPI}

Prior to the start of the TP in both 2013 and 2014, the LMDP education specialists presented to the student teachers a detailed comparative analysis of the language and mathematics systemic results over a four-year period in each of the three schools. This provided a contextual understanding of the schools and an opportunity for students to gain insight into the performance levels of the schools in which they were to be placed. In addition to the presentations, students were visited informally in the schools on a weekly basis by the supervisor (instead of the usual two supervision visits during the six-week period). Furthermore, formalised campus-based weekly reflection and supervision sessions (referred to as 'Friday Reflection and Planning Sessions') were facilitated by the university supervisor and LMDP.

The Friday sessions offered weekly opportunities for students to de-brief, reflect, connect and share experiences as well as engage in collaborative lesson planning with each other, their supervisor and the LMDP. Often sessions focused on critical incidents experienced by students during the preceding week, thus creating practical examples which were linked to theory. Additonally, demonstration lessons and advice on lesson planning by LMDP staff took place during these sessions. Premised on the notion of 'reflectionin-the-midst-of-action' (Sykes and Dean, 2013) rather than 'reflection-onaction', these Friday sessions offered a supportive space for students to reflect on their teaching practice with their university supervisor and members of the 
LMDP. Commenting on the value of the Friday sessions, one of the student reflects:

I think that for the future it's actually quite important. You do get to connect ... I think that initially, starting out, knowing that you're going to be connecting every Friday, I think is going to make people more inclined to go for TP (in the partner schools) ...

Added to this, another student suggests:

You might have noticed something one week that you didn't bring up in the meeting ... then the next week you come back and you can expand on what you said before so you don't have to expalin the story fully again.

From the perspective of the LMDP, one of the education specialists reflects on their role in supporting the student teachers during the Friday sessions:

The support that we were able to give to the students during the Friday afternoon sessions also seemed to be effective. Discussions around the content that they were to mediate, especially being able to articulate their teaching strategies and having us objectively critiquing their ideas served to make them more confident about their lesson presentations.

Assembling at the university every Friday contributed to students' sense of belonging. Functioning as both a 'communal' (Rusznyak and Moosa, 2014) and 'communicative space' (Eady, Drew and Smith, 2015), and with the support of the LMDP, the Friday sessions provided opportunities within a neutral space for students to connect with each other, and significantly, to connect practice to expert knowledge (Darling-Hammond, Hammerness, Grossman, Rust and Shulman, 2005), which, as these authors advise, must be built into pre-service learning experiences. The value of student teachers working collaboratively with each other, together with their mentors and university educators is frequently regarded as strengthening pre-service practice (Rutgers and Reddy, 2013; Darling-Hammond et al., 2005; Desimone, Porter, Garet, Yoon and Birman, 2002; Birman, Desimone and Porter, 2000; Cohen and Hill, 2000, 2001; Garet, Porter, Desimone, Birman and Yoon, 2001). This is further illustrated by the additional support students gave to each other.

\section{Peer support}

After the first action reflection cycle, it was agreed that in 2014 students would be placed in pairs in each class rather than individually (as in 2013). 
This shift was intended to encourage students to engage in collaborative planning and reflection, to share experiences (Mitchell, De Lange, Balfour and Islam, 2011) and to support each other with regard to classroom management and teaching. The value of peer support was experienced furthermore through students travelling together to and from the township thus providing a regular shared communicative space.

After realising that a particular idea she had tried in class was not effective, a student reflects:

[It] did not work at all, I will have to come up with a plan ... I will ask my colleagues for advice. The good thing about travelling with four colleagues is that we do lesson reflections in the car and exchange ideas ... The reflection in the car, after school, with my colleagues has been valuable. We share our frustrations and achievement, as well as exchanging ideas of improving our teaching.

Reflecting on her TP in general, a different student comments on the 'car lesson reflections':

I will miss the car lesson reflections. I learnt a lot from my colleagues. There were times in the morning when I did not even feel like talking but my mood was always lifted up by the stories in the car.

Support offered by the university supervisor and LMDP education specialists coupled with peer collaboration resulted in students feeling well supported. Despite differing experiences from their school-based mentors, students agreed that they had benefited immeasurably from the collaborative support they received. The following extract from a student teacher illustrates this:

In some ways (the TP) was easier than I expected. The support from lecturers, the LMDP and the other students ... made a huge difference. I learnt a lot just from the other students, seeing them teach, hearing how the others tackled issues in class. The guidance we got on lessons and on how to teach them, helped a great deal and I could notice in the lessons I had help with, the difference some input ... makes. I think this kind of mentoring process will really help the (student) teachers ... and motivate them too.

Similarly, another student comments on the value of the LMDP presentation at the start of the teaching practice, which contributed to her feeling well prepared for her school environment:

I was more mentally prepared for going to this TP than the first ... knowing the demographics of the school ... knowing the statistics of the school such as the learners systemic test results helped to prepare me more. 
Two students reflected on their Teaching Practice more broadly in their journal entries:

This was an amazing experience and I really feel that I learnt a lot about teaching and about pedagogy. I really feel that this should be offered to future PGCE classes. This experience allows student teachers to see what the education of South Africa is like and learn how to adapt their teaching styles.

This TP has brought me to a firm, absolute, undoubting confirmation that I want to pursue a life in education, that I am truly passionate and committed to teaching . . This experience has been one of the most valuable to me as a teacher and a person ... It has changed me for the better and opened my eyes to 'the bigger picture', I look forward to seeing where things take me from here.

Appreciation for the collaborative support was particularly noted in the light of the mentors being preoccupied with other tasks. Students frequently commented on their mentors' busy schedules, noting in particular the multiple roles mentor teachers were expected to play. Added to their mentoring responsibilities were admin demands, dealing with parents and preparing learners for the Annual National Assessments, ${ }^{4}$ resulting in high levels of pressure (Hobson, 2002).

\section{Imagining mentoring}

The reality of mentors' heavy work loads and extra responsibilities led to students imagining mentoring arrangements in which fewer demands could be placed on mentor teachers and in which their roles might be re-defined. In the context of the USPI's collaborative support programme, students agreed in the focus group discussions that expectations of teachers to observe and comment on as many student-taught lessons could be reduced, especially if two students were placed in each class.

Recognising that a postive TP requires distributed support and is not contingent on the support from the mentor teacher only, a student reflects:

From the teaching practical, I feel that I got a lot of support from people, which made the experience a lot easier. This is something that I wanted to have more of in my first teaching practice. 
Having described students' reflections on support they received during their TP in the first and second action-research cycle, we turn now to the mentor teachers' reflections. We begin the section by describing how mentors viewed themselves in their roles as mentors.

Mentor's reflections of themselves as mentors

Prior to the start of the 2013 TP, the university supervisor held discussions with the mentor teachers at each of the schools, focusing on their roles and expectations in particular, and more broadly on the desired outcomes of the TP (Gravett, Petersen and Petker, 2014). In all cases during these discussions, mentors' personal experience of their own TP had left strong impressions on them (Hall, et al. 2008). Mentors remembered receiving little critical engagement from their own mentor teachers but commented on the friendly assistance when it came to practical tasks. In all cases the mentor teachers regarded their role as practical - that they should "show the students how it's done", as one mentor teacher suggested. This as indicated involved sharing practical tips, from demonstrating the use of teaching and learning aids to helping students complete application forms for teaching posts.

Mentors' perceptions of their roles (Kwan and Lopez, 2005), as outlined above, captured before the $2013 \mathrm{TP}$, correspond with the reflections from both mentors and students following the $2013 \mathrm{TP}$, namely, that critical reflection, input on lesson planning and constructive feedback generally did not take place. These absences reflected mentor teachers' insecurity about their roles which they expressed in the focus group discussions following the TP. Inspite of the initial briefing session, mentors indicated that were still unclear as to what was expected of them, and as a result requested further assistance from the university in developing their mentoring skills prior to the 2014 TP period. In response to this request, the researchers developed a university-certified Short Course in mentoring to deepen mentoring practices in preparation for the $2014 \mathrm{TP}$.

\section{Support for mentors (2014)}

The Mentoring Short Course was introduced prior to the commencement of the 2014 TP. The Short Course aimed to support mentor teachers in performing their mentoring roles more effectively. As agreed, mentoring activities would include scheduling meetings to introduce the mentors to the 
other grade teachers; discussion of lesson plans with the students; discussion of learners' responses to the lessons and collaborative preparation for the following week.

Mentors and students were required to set up an initial meeting to agree on the roles of the mentors and to clarify students' expectations so to avoid making assumptions (Mutemeri and Chetty, 2011; Hobson 2002; Zanting, et al. 2001; Gravett, et al. 2014). Echoing these authors, it is critical for student teachers to articulate their particular mentoring needs to avoid confusion about roles and responsibilties. In order to derive reciprocal benefits, Stanulis and Russell (2000) maintain that conversations about mentoring must take place in such a way that perceptions are made explicit and realistic roles can be negotiated.

In addition to clarifying roles and expectations, the six-week mentoring course included a work-integrated learning component requiring that the mentor teachers write reflective journals which were reviewed on a one-onone basis with an experienced mentor appointed by the USPI. The Course Mentor visited each mentor teacher at the beginning and in the middle of the TP period to support the mentors in their mentoring of the student teachers. Daily logs of all mentoring activities were used as tools for reflection with the Course Mentor.

Analysis of the mentor logs at the end of the practicum period showed that five out of six mentor teachers recorded that their students had "taught lessons well", however this was not explained or substantiated. Furthermore, as noted in the mentor logs all of the mentor teachers felt that they had mentored their students well however only one mentor teacher documented that the types of activities covered in the Short Course (above) had been undertaken.

In developing the Mentoring Short Course the researchers anticipated that exposure to practice-based mentoring would enable mentors to be better equipped to perform mentoring roles as expected by the university. However, data from the second action research cycle suggested that this was not the case. On the whole, the Mentoring Short Course seemed to have produced limited change in mentoring practices compared with the first action research cycle with respect in particular to critical reflection and constructive feedback. 
Despite input at the start of the Short Course on roles and expectations of mentors, evidence from the study suggests that the dominant role played by mentor teachers in their engagement with the students remained at the level of hospitality. Expressed through a caring and nurturing attitude, the mentors saw it as their responsibility to ensure that the students were well cared for and that they were granted the opportunity and space to practice their teaching as often as possible. In this sense they played something of an oversight role in ensuring that students were teaching well enough both for the students' benefit and for learners to achieve the required curriculum goals.

Reflections of the mentors suggest that they derived both personal and organisational benefits from having been involved in the mentoring process. At a personal level, they reported gaining confidence in their own strengths as teachers through learning new skills, gaining ideas from the students and from feeling strongly affirmed by them. The experience of mentoring students boosted mentors' self-esteem and, as one mentor stated, made her feel as though she "could make a contribution". Mentors positively acknowledged the impact they made on the lives of the student teachers. As one mentor teacher recounts:

I'm a person who is not sure whether I am doing good. But from the experience I had with these mentees I can see that I have affected a change in their lives.

At the level of the school, mentors stated that the placement of students had a positive effect on the school's reputation:

The project put the school on the map. Word spreads quickly and enrolments increased because there is a perception in the community that this school has some good support from the university and they are getting a better education for their children.

Mentor teachers appreciated being exposed to alternative sources of information through the use of technology and through sourcing information. Perhaps most significantly, mentors agreed that the presence of students in the school encouraged teachers to use more English in their lessons. This resulted in less code-switching in their teaching and in the learners speaking more frequently English.

Distributed mentorship: from the mentors' perspective

The theme of distributed mentorship emerged once again from the 2014 data 
as mentors themselves argued for greater distribution of mentoring across the school: "As much as you want to work, others must also be developed", argued one teacher, while another stated:

... at the end of the day the results of the system do not depend on us (the mentor teachers). It is a combination of all of us. So it needs us as schools to come to the table together with our managers ... (Mentoring) is more of a school responsibility.

However where distributed mentorship did take place, this was not without its challenges. Mentors reported for example that at times it was difficult to gather and collate feedback from the non-mentor teachers as this was not always forthoming. A further issue was that some non-mentors regarded lessons taught by students as free periods:

... the other teachers who now had the mentees were regarding the time students were scheduled to be in their classes as free periods. This needed to be addressed but created an uncomfortable situation. If these teachers are not in the classroom they are not in a position to provide feedback to the students.

Despite these challenges, mentor teachers agreed that mentorship should be distributed across the school and argued that this might bring about postive changes in future TP placements - for the teachers, the students and the learners. As agreed, exposure by more teachers to alternative styles and strategies would in turn positively impact on learners' performance levels.

\section{Conclusion}

The purpose of this study was to describe a collaborative support programme for student teachers' and their school-based mentors in diverse school contexts. This programme, anchored within an existing university school partnership, was premised on the understanding that university-school partnerships have a crucial role to play in the initial professional development of teachers and that this is a responsibility that should be shared by both the university and the school.

What emerged from the data is that student teachers valued the emotional support offered by their mentors in helping them navigate the school terrain an experience markedly different to that of their previous TP. Upon reflection by the students, they agreed that the support they received from their mentors was more than they could have expected given the nature and circumstances 
of the mentors' everyday working lives and their daily struggle to cope with the many competing demands on their time. Given the contextual challenges faced by teachers on a daily basis, student teachers imagined the possibility of a different model of mentorship.

While we fully acknowledge that the role of mentor teachers is crucial in supporting students, especially in challenging situations (Pennefather, 2008; Hobson, 2002), and that improving "mentoring quality impacts upon the student teacher's school practice as a whole" (Pennefather, 2008, p.91), we hold that in contexts in which student teachers are receiving additional support, it is possible, and indeed necessary to re-conceptualise the role of the traditional mentor teacher. This re-imagining involves the distribution of mentoring functions from a few designated mentor teachers to include a wider range of teachers at the school.

In this study, through the USPI's integrated support strategy, other mechanisms were put in place to support students in their pedagogic needs which meant that students did not have to rely solely on their mentors for this input. These mechanisms purposefully included a range of both school and campus-based activities involving academic staff members; education specialists; school-based mentors and significantly, the students themselves. The on-campus, Friday reflection and planning sessions offered a space for student teachers to engage with the LMDP education specialists and their academic supervisor - and to interact with each other through sharing ideas and reflecting on practice.

In order to ensure that effective support is offered to student teachers, and that value is added to the school during - and beyond - the TP period, we argue that models of support need to actively include mechanisms that extend mentoring practices beyond the boundaries of the mentoring relationship, so that key mentoring functions are shared. A move to distributing support would enhance the value of using mainstream schools as Professional Practice Sites, thus providing students - and indeed teachers - with an opportuniy to derive maximum benefit from the pre-service practicum.

Herein lies the significant learning of this two-year pilot project: the extent to which student teachers' pre-service learning can be significantly enhanced by a model that draws on the combined strengths of in-school support by mentors and teachers, collaborative support between students, and on-campus pedagogic support from the university supervisor and education specialists. 
In concluding, we argue that the preparation of students for their initial teacher training in a wide range of contexts, requires a robust programme of support, not only at the level of the university, but also at the level of the school. A collaborative, integrated and distributed support strategy pitched at both levels is critical to optimise support for the student and mentor teacher, especially in contexts that are socially and educationally challenging. This would enable student teachers to be better prepared for teaching in diverse school contexts and to make a positive and meaningful contribution in schools where this is most needed.

\section{References}

Birman, B., Desimone, M. and Porter, A. 2000. Designing professional development that works. Educational Leadership, 57(8): pp.28-33.

Christie, P., Butler, D. and Potterton, M. 2007. Report of the Ministerial Committee: schools that work. Pretoria: Department of Education.

Cohen, D.K. and Hill, H.C. 2000. Instructional policy and classroom performance: the mathematics reform in California. Teachers College Record, 102(2): pp.294-343.

Cohen, D.K. and Hill, H.C. 2001. Learning policy: when state education reform works. New Haven, CT: Yale University Press.

Corrigan, D. 2000. The changing role of schools and Higher Education Institutions with respect to community-based interagency collaboration and interprofessional partnerships. Peabody Journal of Education, 75(3): pp.176-195.

Darling-Hammond, L., Hammerness, K., Grossman, P., Rust, F. and Shulman, L. 2005. The design of teacher education programs. In DarlingHammond, L. and Bransford, J. (Eds), Preparing teachers for a changing world: what teachers should learn and be able to do. San Francisco: JosseyBass, pp.390-441. 
Deppeler, J. 2006. Improving inclusive practices in Australian schools: creating conditions for university/school collaboration in inquiry. European Journal of Education, 21(3): pp.347-360.

Deppeler, J. 2007. Leading learning: inquiry and collaboration. Paper presented as part of the symposium: cultivating teachers' values, knowledge and skills for critical reflection and leading change in schools, Redesigning pedagogy: culture, knowledge and understanding conference. National Institute of Education, Singapore, 28-30 May 2007.

Desimone, L.M., Porter, A.C., Garet, M.S., Yoon, K.S. and Birman, B.F. 2002. Effects of professional development on teachers' instruction: results from a three-year longitudinal study. Educational Evaluation and Policy Analysis, 24: pp.81-112.

Eady, S., Drew, V. and Smith, A. 2014. Doing action research in organizations: using communicative spaces to facilitate (transformative) professional learning. Action Research, 13(2): pp.105-122.

Fink, C.B., Isabelle, A.D. and De Groot, C. 2010. Our quest for mutualism in University-school partnerships. The Educational Forum, 74(4): pp.306-317.

Fleisch, B. 2008. Primary education in crisis: why South African schoolchildren underachieve in reading and mathematics. Cape Town: Juta.

Garet, M., Porter, A., Desimone, L., Birman, B. and Yoon, K. 2001. What makes professional development effective? Analysis of a national sample of teachers. American Education Research Journal, 38(4): pp.915-945.

Gravett, S., Petersen, N. and Petker, G. 2014. Integrating foundation phase teacher education with a 'teacher school' at the University of Johannesburg. Education as Change, 18(1): pp.107-119.

Hall, K.M., Draper, R.J., Smith, L.K. and Bullough, J.F. 2008. More than a place to teach: exploring the perceptions of the roles and responsibilities of mentor teachers. In Mentoring \& Tutoring: Partnering in Learning, 16(3): pp.328-345. 
Hobson, A.J. 2002. Student teachers' perceptions of school-based mentoring in Initial Teacher Training (ITT). Mentoring \& Tutoring: Partnership in Learning, 10(1): pp.5-20.

Hudson, P., Spooner-Lane, R. and Murray, M. 2013. Making mentoring explicit: articulating pedagogical knowledge practices. School Leadership \& Management, 33(3): pp.284-301.

Islam, F. 2011. School-university partnerships in preparing new teachers: possibilities and limitiations. In Islam, F., Mitchell, C., De Lange, N., Balfour, R. and Combrinck, M. (Eds), School-University partnerships for educational change in rural South Africa. USA: The Edwin Mellen Press, pp.41-57.

Kemmis, S. and McTaggart, R. 2000. Participatory action research. In Denzin, N. and Lincoln, Y. (Eds), Handbook of qualitative research (2nd edition). Thousand Oaks, CA: Sage, pp.567-605.

Kiggundu, E. and Nayimuli, S. 2009. Teaching practice: a make or break phase for student teachers. South African Journal of Education. Vol. 29: pp.345-358

Koshy, E., Koshy, V. and Waterman, H. 2010. Action research in healthcare. London: SAGE.

Kwan, T. and Lopez-Real, F. 2005. Mentors' perceptions of their roles in mentoring student teachers. Asia-Pacific Journal of Teacher Education, 33(3): pp.275-287.

Mitchell, C., De Lange, N., Balfour, R. and Islam, F. 2011. Transforming teacher education? A rural teacher education project experience. In Islam, F., Mitchell, C., De Lange, N., Balfour, R. and Combrinck, M. (Eds), SchoolUniversity partnerships for educational change in Rural South Africa. USA: The Edwin Mellen Press, pp.59-79.

Mertler, C.A. 2012. Action research: improving schools and empowering educators ( $3^{\text {rd }}$ edition). London: SAGE.

Meyer, J. 2000. Using qualitative methods in health related action research. British Medical Journal, 320: pp.178-181. 
Mukeredzi, T. 2013. The journey to becoming teaching professionals in rural South Africa and Zimbabwe. Australian Journal of Teacher Education, 38(10): pp.83-104.

Mukeredzi, T. and Mandrona, A. 2013. The journey to becoming professionals: student teachers' experiences of teaching practice in a rural South African context. International Journal of Educational Research, 62: pp.141-151.

Mukeredzi, T., Mthiyane, N. and Bertram, C. 2015. Becoming professionally qualified: the school-based mentoring experiences of parttime PGCE students. South African Journal of Education, 35(2).

Mushoriwa, T.D. and Mavuso, M.P. 2014. Student teachers' views of the impact of school experience programme on their perceptions of the teaching profession. Mediterranean Journal of Social Sciences, 5(8): pp.336-342.

Mutemeri, J. and Chetty, R. 2011. An examination of university/school partnerships in South Africa. South African Journal of Education, 31: pp.505-517.

Nehring, J. and O'Brien, E. 2012. Strong agents and weak systems: university support for school level improvement. Journal of Education Change, 13: pp.449-485.

Pennefather, J. 2008. 'Rural' schools and universities: the use of partnerships as a teaching strategy in enhancing a positive response to rurality.

Perspectives in Education, 26(2): pp.81-94.

Pennefather, J. 2011. Landscape shapes mindscape: partnerships as agency in a community of learning. In Islam, F., Mitchell, C., De Lange, N., Balfour, R. and Combrinck, M. (Eds), School-University partnerships for educational change in rural South Africa. USA: The Edwin Mellen Press, pp. 211-229.

Rajuan, M., Beijaard, D. and Verloop, N. 2008. Student teachers' perceptions of their mentors as internal triggers for learning. Teaching Education, 19(4): pp.279-292. 
Ramsey, G. 2000. Quality matters: revitalising teaching: critical times, critical choices. Report of the Review of Teacher Education and Training, New South Wales. New South Wales Department of Education and Training: Sydney.

Robinson, M. 2014. Selecting TP schools across social contexts: conceptual and policy challenges from South Africa. Journal of Education for Teaching, 40(2): pp.114-127.

Robinson, M. 2015. Teaching practice in initial teacher education: research and interventions in South Africa. Draft report: A study conducted for the Zenex Foundation. Cape Town, South Africa.

Rusznyak, L. and Moosa, M. 2014. Supporting student teachers through their first attempts at teaching: possibilities and limitations afforded by schoolbased and campus-based models of support. Education as Change, 18(S1): pp.S91-S105.

Rutgers, L. and Reddy, C. 2013. Cognitive coaching: strengthening Grade R teachers' leadership capacity as supervising partners of student teachers. South African Journal of Higher Education, 27(4): pp.1005-1020.

Shulman, L.S. 2005. Signature pedagogies in the professions. Daedalus, 134(3): pp.52-59.

South Africa. Department of Higher Education and Training. 2011. Minimum Requirements for Teacher Education Qualifications. Government Gazette No. 34467.

South Africa. Departments of Basic Education and Higher Education and Training. 2011. Integrated Strategic Planning Framework for Teacher Education and Development in South Africa. 2011-2025. http://www.education.gov.za

Spaull, N. 2012. Poverty and privilege: primary school inequality in South Africa. Stellenbosch Economic Working Papers:13/12. Stellenbosch: Stellenbosch University and the Bureau for Economic Research.

Stanulis, R.N. and Russell, D. 2000. 'Jumping in': trust and communication in mentoring student teachers. Teaching and Teacher Education, pp.16: pp.65-80. 
Stemler, S. 2001. An overview of content analysis. Practical Assessment, Research \& Evaluation, 7(17): pp.1-10.

Sykes, C. and Dean, B.A. 2013. A practice-based approach to student reflection in the workplace during a work-integrated learning placement. Studies in Continuing Education, 35(2): pp.179-192.

Teitel, L. 2008. School/Uníversíty collaboration: the power of transformative partnerships. Childhood Education, 85(2): pp.75-80.

Van der Berg, S., Burger, C., Burger, R. De Vos, M., Du Rand, G. and Gustafsson, M. et al. 2011. Low quality education as a poverty trap. Stellenbosch: Stellenbosch University.

Yamauchi, F. 2011. School quality, clustering and government subsidy in post-aparteid South Africa. Economics of Education Review, 30: pp.146-156.

Zanting, A., Verloop, N. and Vermunt, J. 2001. Student teachers' beliefs about mentoring and learning to teach during teaching practice. British Journal of Educational Psychology, 71: pp.57-80.

Zeichner, K. 2010. Rethinking the connections between campus courses and field experiences in College- and University-based teacher education. Journal of Teacher Education, 61(1-2): pp.89-99.

Patti Silbert

Claire Verbeek

University of Cape Town

patti.silbert@uct.ac.za

clare.verbeek@uct.ac.za 